\title{
Complex experiment on studying the microphysical, chemical, and optical properties of aerosol particles and estimating the contribution of atmospheric aerosol-to-earth radiation budget
}

\author{
G. G. Matvienko ${ }^{1}$, B. D. Belan ${ }^{1}$, M. V. Panchenko ${ }^{1}$, O. A. Romanovskii ${ }^{1,2}$, S. M. Sakerin ${ }^{1}$, D. M. Kabanov ${ }^{1}$, \\ S. A. Turchinovich ${ }^{1}$, Y. S. Turchinovich ${ }^{1}$, T. A. Eremina ${ }^{1}$, V. S. Kozlov ${ }^{1}$, S. A. Terpugova ${ }^{1}$, V. V. Pol'kin ${ }^{1}$, \\ E. P. Yausheva ${ }^{1}$, D. G. Chernov ${ }^{1}$, T. B. Zhuravleva ${ }^{1}$, T. V. Bedareva ${ }^{1}$, S. L. Odintsov ${ }^{1}$, V. D. Burlakov ${ }^{1}$, \\ A. V. Nevzorov ${ }^{1}$, M. Y. Arshinov ${ }^{1}$, G. A. Ivlev ${ }^{1}$, D. E. Savkin ${ }^{1}$, A. V. Fofonov ${ }^{1}$, V. A. Gladkikh ${ }^{1}$, A. P. Kamardin ${ }^{1}$, \\ Y. S. Balin ${ }^{1}$, G. P. Kokhanenko ${ }^{1}$, I. E. Penner ${ }^{1}$, S. V. Samoilova ${ }^{1}$, P. N. Antokhin ${ }^{1}$, V. G. Arshinova ${ }^{1}$, D. K. Davydov ${ }^{1}$, \\ A. V. Kozlov ${ }^{1}$, D. A. Pestunov ${ }^{1}$, T. M. Rasskazchikova ${ }^{1}$, D. V. Simonenkov ${ }^{1}$, T. K. Sklyadneva ${ }^{1}$, G. N. Tolmachev ${ }^{1}$, \\ S. B. Belan ${ }^{1}$, V. P. Shmargunov ${ }^{1}$, A. S. Kozlov ${ }^{3}$, and S. B. Malyshkin ${ }^{3}$ \\ ${ }^{1}$ V. E. Zuev Institute of Atmospheric Optics SB RAS, 1 Academician Zuev sq., 634021, Tomsk, Russia \\ ${ }^{2}$ National Research Tomsk State University, 36 Lenina Ave., 634050, Tomsk, Russia \\ ${ }^{3}$ Voevodsky Institute of Chemical Kinetics and Combustion SB RAS, 3 Institutskaya Ave., 630090, Novosibirsk, Russia
}

Correspondence to: O. A. Romanovskii(roa@iao.ru)

Received: 14 April 2015 - Published in Atmos. Meas. Tech. Discuss.: 12 June 2015

Revised: 7 October 2015 - Accepted: 9 October 2015 - Published: 27 October 2015

\begin{abstract}
The primary objective of this complex aerosol experiment was the measurement of microphysical, chemical, and optical properties of aerosol particles in the surface air layer and free atmosphere. The measurement data were used to retrieve the whole set of aerosol optical parameters, necessary for radiation calculations. Three measurement cycles were performed within the experiment during 2013: in spring, when the aerosol generation is maximal; in summer (July), when atmospheric boundary layer altitude and, hence, mixing layer altitude are maximal; and in late summer/early autumn, during the period of nucleation of secondary particles. Thus, independently obtained data on the optical, meteorological, and microphysical parameters of the atmosphere allow intercalibration and inter-complement of the data and thereby provide for qualitatively new information which explains the physical nature of the processes that form the vertical structure of the aerosol field.
\end{abstract}

\section{Introduction}

The climate change observed for already more than 1 decade is recognized by the whole global community. Numerous national and international programs are devoted to investigation of possible causes and prediction of further climatic tendencies. Despite the common recognition of this problem, there is no consensus on the role of human activity in the global climate change. Thus, the studies of Antarctic ice cores have shown that there were several periods of global warming for the last 650000 years (Solomon et al., 2007) accompanied by an increase in the concentration of major greenhouse gases $\left(\mathrm{CO}_{2}, \mathrm{CH}_{4}\right.$, and $\left.\mathrm{N}_{2} \mathrm{O}\right)$. It was found that the increase in the temperature in the Antarctic region started several centuries before the increase in the $\mathrm{CO}_{2}$ concentration (Monnin et al., 2001).

Although an important role of aerosols in climate changes is well established, the level of understanding of the indirect effect of aerosols in radiative changes remains very low. This fact complicates significantly the prediction of global changes in the Earth's climate.

The permanent development and improvement of climatic models require a significantly greater amount of field measurement data from different regions of the world. The terri- 
tory of Siberia, occupying about $10 \%$ of the world's land, is practically not covered by the modern observation network. Meanwhile, Siberia lies in several climatic zones and its ecosystems are very different, and therefore the intensity of sources and sinks of atmospheric admixtures should vary significantly.

Taking into account the fact that every of methods for investigation of aerosol parameters is informative only in a certain wavelength range, only the combined analysis of all available experimental data can provide the correct reconstruction of the complete optical pattern of tropospheric aerosol in a particular region.

The objective of this study was simultaneous measurements of microphysical, chemical, and optical properties of aerosol particles in the surface air layer and free atmosphere with a unique set of ground-based, airborne, and spaceborne instruments in order to draw a complete pattern of the composition and state of the atmosphere over the territory of Western Siberia. In this connection, the following tasks were formulated:

- modernization and intercalibration of developed measurement tools;

- carrying out of measurement cycles;

- retrieval of the whole set of microphysical, chemical, and optical parameters of aerosols from experimental findings.

Analysis of the data obtained will promote formation of the set of input parameters for radiative calculations; their use allows more accurate estimation of the contributions of different atmospheric components into formation of the radiative budget of the Earth on the regional scale. The results obtained on the basis of data of the complex experiments carried out at IAO SB RAS in 2010-2012 can be considered as an example of the joint use of empirical data and numerical simulation of solar radiation.

\section{Measurement system}

The measurement system developed provides sunphotometric measurements of the aerosol optical depth (AOD) of the atmosphere, acoustic sounding of the boundary layer, laser sensing of the aerosol content in the troposphere and stratosphere, measurement of the gas composition of the atmosphere (including greenhouse gases), and measurement of meteorological parameters of air, in particular with weather balloons.

The composition and purpose of individual elements of the measurement system are summarized in Table 1 .

Let us first consider the systems used for measurements in the surface air and then describe the devices for measuring of the integral content of the sought parameters and their vertical distributions. Continuous measurements of the concentra- tions of minor gas constituents (MGCs) were carried out at three IAO SB RAS stations for monitoring the atmospheric composition: Fonovaya Observatory, TOR station, and Basic Experimental Complex (BEC). The measured parameters are summarized in Table 2; the operation of all the stations is described in detail in Arshinov et al. (2007).

For controlling the measurements and the state of the systems, all data from each station are transmitted to the central server every hour. As a result, the state of the atmosphere is monitored in the nearly online mode. The graphic presentation of the monitored parameters is available on the website http://lop.iao.ru/activity/?id=mes, which is hourly updated. The interface allows selection of different options for viewing the current information both separately for each station and for a particular parameter measured at all the three stations.

To study the vertical distribution of the climatically significant components of the troposphere, we used the analytical equipment (Fig. 1) installed aboard the Tu-134 OPTIK flying laboratory (Anokhin et al., 2011).

Below we describe the equipment used to measure atmospheric admixtures being major contributors to the radiative forcing.

To study the vertical distribution of the main greenhouse gases, we used a Picarro G2301-m precision gas analyzer specially designed for in-flight measurements of carbon dioxide, methane, and water vapor concentrations with a frequency of $1 \mathrm{~Hz}$ (http://www.picarro.com/products_solutions/ trace_gas_analyzers/co_co2_ch4_h2o). The operating principle of the gas analyzer is based on the cavity ring-down spectroscopy technique, which allows the determination of the spectral characteristics of gas molecules in an optical cavity. This device is the world's best, since the precision of $\mathrm{CO}_{2}, \mathrm{CH}_{4}$, and $\mathrm{H}_{2} \mathrm{O}$ measurements is $<200 \mathrm{ppb},<1.5 \mathrm{ppb}$, and $<150 \mathrm{ppm}$, respectively.

The ozone concentration was measured with a Thermo Environmental Instruments (TEI) model 49C UV photometric gas analyzer modified for measurements from aircrafts of different types (Marenco et al., 1998). The measurement precision was $1 \mathrm{ppb}$ at integration time of $4 \mathrm{~s}$.

The vertical structure of the distribution of atmospheric aerosols was retrieved with the use of two types of devices. The first type is a diffusion aerosol spectrometer (DAS), which allows the number distribution of nanoaerosols to be retrieved in the size range from 3 to $200 \mathrm{~nm}$ in 20 size intervals. The DAS consists of eight-channel mesh-type diffusion battery (DB) and the condensation particle counter. The principle of particle separation by size is based on the size dependence of the diffusion coefficients of nanoparticles. As a result, particles of different sizes passing through porous media have different deposition rates: smaller particles leave the flow more quickly, and thus the coefficient of particle passage through such a medium carries the information about the particle size. The particle concentration is measured after each DB channel with a WCPC 3781 condensation particle 


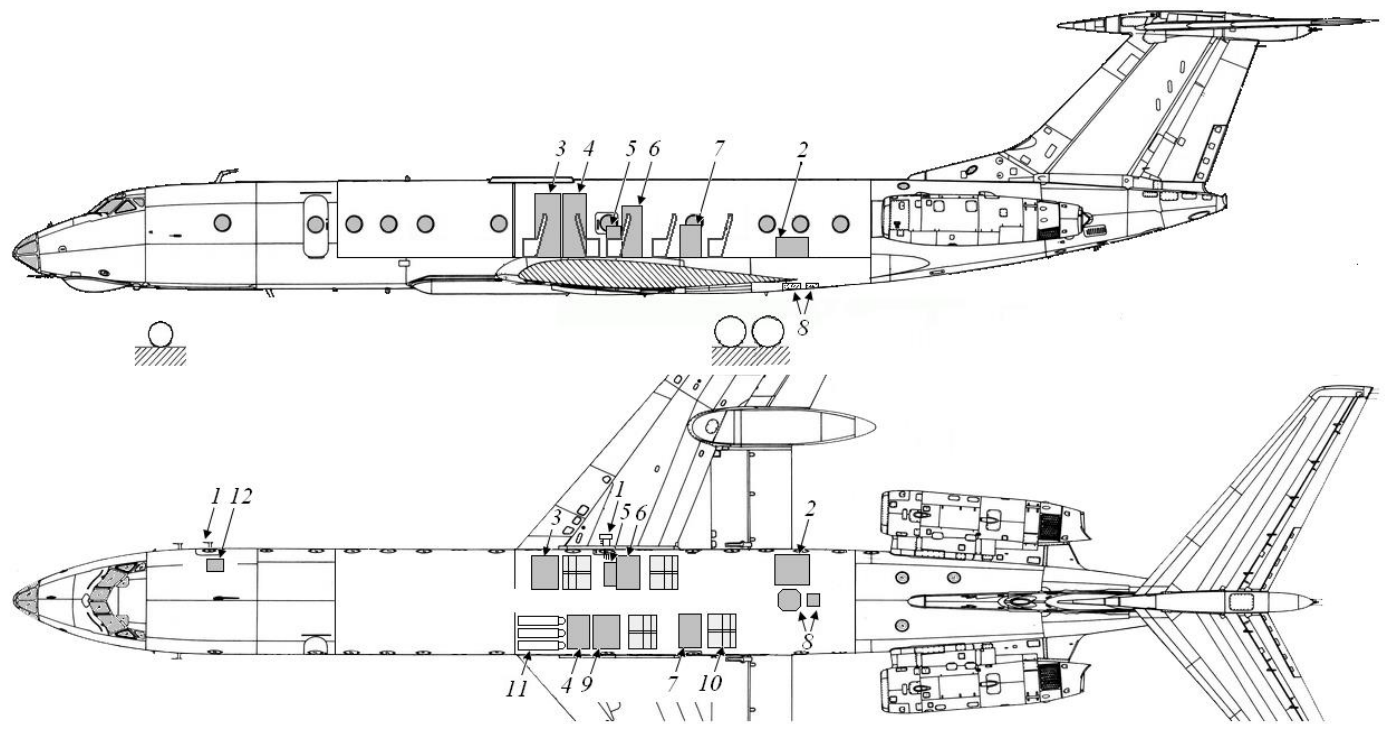

Figure 1. Arrangement of scientific equipment onboard the Tu-134 OPTIK flying laboratory: 1 - air intakes; 2 - power supply unit for airborne equipment; 3 - instrument rack for the gas analyzers: $\mathrm{O}_{3}$ (TEI model 49C), $\mathrm{SO}_{2}$ (T-API 100E), and DAS (diffusion aerosol spectrometer); 4 - instrument rack for the gas analyzers: $\mathrm{CO}_{2}$ (CONDOR), $\mathrm{CO}_{2} / \mathrm{CH}_{4} / \mathrm{H}_{2} \mathrm{O}$ (Picarro G2301-m), $\mathrm{O}_{3}$ (TEI model 49C), and CO (TEI model 48C); 5 - rack for the filter-aspiration setup, laser aerosol spectrometer (Grimm model 1.109), and $\mathrm{O}_{3}$ gas analyzer (OPTEK $3.02 \mathrm{P}) ; 6$ - instrument rack for aethalometer and flow-through nephelometer (FAN); 7 - rack for the central onboard computer; 8 - camera windows; 9 - instrument rack for the $\mathrm{CO}_{2}$ gas analyzer (LI-6262) and portal of air sampling into flasks; 10 - operator chairs; 11 - span gas cylinders; 12 - device for sampling onto filters for analysis of the organic component of aerosol.

counter (TSI inc., USA). After every scan of all DB channels, the size spectrum is retrieved with the use of the algorithm developed by A. N. Ankilov and S. I. Eremenko (Eremenko and Ankilov, 1995) with regard to the WCPC 3781 counting efficiency. Due to the use of the WCPC 3781 condensation particle counter with a response time of $<2 \mathrm{~s}$, the full size distribution of nanoparticles is obtained in $80 \mathrm{~s}$.

The second type is a Grimm 1.109 laser aerosol spectrometer (Grimm Aerosol Technik GmbH \& Co., Germany), which measures the aerosol particle number density in 31 size intervals: $0.25,0.28,0.3,0.35,0.4,0.45,0.5,0.58,0.65$, $0.7,0.8,1.0,1.3,1.6,2,2.5,3,3.5,4,5,6.5,7.5,8.5,10$, $12.5,15,17.5,20,25,30$, and $32 \mu \mathrm{m}$. The operating principle of this spectrometer is based on the dependence of the scattered radiation intensity on the particle size. At a known air-flow rate, the pulse repetition frequency allows the concentration of particles in air to be determined.

Thus, a combination of these two spectrometers forms an aerosol system covering the size range from $3 \mathrm{~nm}$ to $32 \mu \mathrm{m}$ with a good resolution.

The temperature-wind sounding was carried out with a Vaisala DigiCORA ${ }^{\circledR}$ MW31 radiosonde (Vaisala R92SGP, http://www.vaisala.ru). The combination of this radiosonde and a GPS correlator with DigiCORA ${ }^{\circledR}$ system provides the world's highest level of measurements of the atmospheric pressure $(P)$, temperature $(T)$, and relative air humidity $(U)$, as well as wind measurements.
Several types of sun photometers are used in measurements of AOD and atmospheric column water vapor. In 2012, two devices were used:

1. SP-9 multiwavelength sun photometer for regular measurements of AOD in the 0.34-2.14 $\mu \mathrm{m}$ spectral range (16 spectral channels) and atmospheric column water vapor, as well as for retrieval of aerosol microstructure parameters (Sakerin et al., 2004, 2012);

2. CIMEL CE 318 sun-sky radiometer of the AERONET global network for measurements of AOD in the 0.34$1.02 \mu \mathrm{m}$ spectral range, water vapor content $W$, asymmetry factor of aerosol scattering phase functions, aerosol single scattering albedo, microstructure parameters of particles sized from 0.05 to $15 \mu \mathrm{m}$, and others (Holben et al., 1998; Dubovik et al., 1998, 2000; Dubovik and King, 2000).

Aerosol measurements at the stationary IAO SB RAS Aerosol Station (Kozlov et al., 1997, 2008a) are carried out with the use of a technique for studying aerosol properties in local air volumes; that is, air with aerosols is pumped through optical cells (flow-through measurements). The surface aerosol comes to the optical cells by ducts through air intakes installed outside the main building of IAO SB RAS at an altitude of $9 \mathrm{~m}$ above the surface.

The aerosol measurement system includes such devices as angle-scattering nephelometers (Kozlov et al., 2008a; 
Table 1. Composition and purpose of individual elements of the measurement system.

\begin{tabular}{|c|c|c|c|c|c|}
\hline No. & Element & Produced by & $\begin{array}{l}\text { Measurements } \\
\text { since }\end{array}$ & Purpose & URL \\
\hline 1 & TOR station & $\begin{array}{l}\text { IAO } \\
\text { RAS, } \\
\text { Russia }\end{array}$ & 1992 & $\begin{array}{l}\text { Monitoring of meteorological parame- } \\
\text { ters, gas and aerosol composition of air, } \\
\text { and solar radiation in the surface layer }\end{array}$ & $\begin{array}{l}\text { http://lop.iao.ru/eng/index.php/ } \\
\text { about-tor-station/aero-tor }\end{array}$ \\
\hline 2 & $\begin{array}{l}\text { Basic } \\
\text { Experimental } \\
\text { Complex }\end{array}$ & $\begin{array}{l}\text { IAO } \\
\text { RAS, } \\
\text { Russia }\end{array}$ & 1986 & $\begin{array}{l}\text { Monitoring of meteorological parame- } \\
\text { ters, gas and aerosol composition of air, } \\
\text { and solar radiation in the surface layer }\end{array}$ & $\begin{array}{l}\text { http://lop.iao.ru/eng/index.php/ } \\
\text { about-bec/aerosols }\end{array}$ \\
\hline 3 & $\begin{array}{l}\text { Fonovaya (back- } \\
\text { ground) Obser- } \\
\text { vatory }\end{array}$ & $\begin{array}{l}\text { IAO } \\
\text { RAS } \\
\text { Russia }\end{array}$ & 1978 & $\begin{array}{l}\text { Monitoring of meteorological parame- } \\
\text { ters, gas and aerosol composition of air, } \\
\text { and solar radiation in the surface layer }\end{array}$ & $\begin{array}{l}\text { http://lop.iao.ru/eng/index.php/ } \\
\text { about-fonovyi/aerosols-2 }\end{array}$ \\
\hline 4 & $\begin{array}{l}\text { Ty-134 OPTIK } \\
\text { flying laboratory }\end{array}$ & $\begin{array}{l}\text { IAO SB RAS, } \\
\text { Russia }\end{array}$ & 1988 & $\begin{array}{l}\text { Measurement of meteorological param- } \\
\text { eters, gas and aerosol composition of } \\
\text { air, and optical characteristics of air }\end{array}$ & $\begin{array}{l}\text { http://www.iao.ru/en/resources/ } \\
\text { equip/plane/ }\end{array}$ \\
\hline 5 & $\begin{array}{l}\text { DigiCORA } 3 \\
\text { system for radio } \\
\text { sounding of the } \\
\text { atmosphere }\end{array}$ & $\begin{array}{l}\text { Vaisala Oy, } \\
\text { Finland }\end{array}$ & 2006 & $\begin{array}{l}\text { Determination of vertical distribution of } \\
\text { meteorological parameters by contact } \\
\text { tools }\end{array}$ & http://www.vaisala.fi/Vaisala \\
\hline 6 & $\begin{array}{l}\text { SP-9 sun } \\
\text { photometer }\end{array}$ & $\begin{array}{l}\text { IAO } \\
\text { RAS, } \\
\text { Russia }\end{array}$ & 2010 & $\begin{array}{l}\text { Measurement of aerosol optical depth } \\
\text { and water column of the atmosphere }\end{array}$ & $\begin{array}{l}\text { http://link.springer.com/article/ } \\
\text { 10.1134/S102485601304012X }\end{array}$ \\
\hline 7 & Aerosol station & $\begin{array}{l}\text { IAO } \\
\text { RAS, } \\
\text { Russia }\end{array}$ & 1996 & $\begin{array}{l}\text { Measurements of characteristics of sur- } \\
\text { face aerosol }\end{array}$ & http://aerosol.iao.ru/?lang=en \\
\hline 8 & LOZA lidar & $\begin{array}{l}\text { IAO SB RAS, } \\
\text { Russia }\end{array}$ & 1992 & $\begin{array}{l}\text { Determination of aerosol profile at a } \\
\text { distance of } 1-10 \mathrm{~km} \text { in any direction of } \\
\text { the hemisphere }\end{array}$ & $\begin{array}{l}\text { http://www.iao.ru/en/resources/ } \\
\text { equip/lidars }\end{array}$ \\
\hline 9 & $\begin{array}{l}2.4 \text { XLB direct } \\
\text { broadcast } \\
\text { reception } \\
\text { system }\end{array}$ & $\begin{array}{l}\text { Orbital } \\
\text { Systems, } \\
\text { USA }\end{array}$ & 2011 & $\begin{array}{l}\text { Reception of satellite data from } \\
\text { AVHRR, MODIS, and other optoelec- } \\
\text { tronic devices }\end{array}$ & $\begin{array}{l}\text { http://www.orbitalsystems. } \\
\text { com/antenna-products/ } \\
\text { systems/eosdb-systems/ }\end{array}$ \\
\hline 10 & $\begin{array}{l}\text { METEO-2 } \\
\text { ultrasonic } \\
\text { meteostation }\end{array}$ & $\begin{array}{l}\text { IAO } \\
\text { RAS, } \\
\text { Russia }\end{array}$ & 2007 & $\begin{array}{l}\text { Measurement of mean values and char- } \\
\text { acteristics of wind turbulence and air } \\
\text { temperature }\end{array}$ & $\begin{array}{l}\text { http://www.iao.ru/en/resources/ } \\
\text { equip/dev/meteo2/ }\end{array}$ \\
\hline 11 & VOLNA sodar & $\begin{array}{l}\text { IAO SB RAS, } \\
\text { Russia }\end{array}$ & 2006 & $\begin{array}{l}\text { Measurement of vertical profiles of } \\
\text { wind vector components in the atmo- } \\
\text { spheric boundary layer }\end{array}$ & $\begin{array}{l}\text { http://www.iao.ru/en/resources/ } \\
\text { equip/dev/sodar/ }\end{array}$ \\
\hline 12 & $\begin{array}{l}\text { Siberian lidar } \\
\text { station }\end{array}$ & $\begin{array}{l}\text { IAO SB RAS, } \\
\text { Russia }\end{array}$ & 1988 & High-altitude sensing of the atmosphere & $\begin{array}{l}\text { http://www.iao.ru/en/resources/ } \\
\text { equip/sls/ }\end{array}$ \\
\hline
\end{tabular}

Shmargunov et al., 2008), photoelectric particle counters of scattered radiation (Shmargunov and Pol'kin, 2007), and aethalometers (Kozlov et al., 1997, 2008a), that is, devices measuring characteristics of aerosol absorption. A flow-through nephelometer (FAN)-type angular nephelometer measures the angular aerosol scattering coefficient at an angle of $45^{\circ}$ at a wavelength of $0.51 \mu \mathrm{m}$, which is proportional to the concentration of submicron aerosols (Kozlov et al., 2008b). The nephelometer allows the angular scattering coefficient to be measured starting from the level of molecu- lar scattering $\sim 1 \mathrm{M} \mathrm{m}^{-1} \mathrm{ster}^{-1}$. The nephelometer has been calibrated under laboratory conditions against the known value of molecular scattering of radiation by pure air at the pump-down pressure in the nephelometer cell from 760 to $350 \mathrm{~mm} \mathrm{Hg}$. To measure the disperse composition of aerosol particles, a modified PKGTA photoelectric particle counter (particle diameter of $0.4-10 \mu \mathrm{m}$ ) is used (Shmargunov and Pol'kin, 2015).

The mass concentration of black carbon in the composition of aerosol particles is measured with a three-wavelength 
Table 2. Measurement facilities and their characteristics.

\begin{tabular}{|c|c|c|c|c|c|}
\hline \multicolumn{6}{|c|}{ TOR station } \\
\hline Unit & Device/sensor & Parameter & Range & Error & Time constant \\
\hline \multirow[t]{5}{*}{ Weather station } & HIH-3602-C & $T,{ }^{\circ} \mathrm{C}$ & $-40 \ldots+85$ & $\pm 0.1^{\circ} \mathrm{C}$ & $1 \mathrm{~s}$ \\
\hline & HIH-3602-C & $U, \%$ & $0 \ldots 100$ & $\pm 2 \%$ & $1 \mathrm{~s}$ \\
\hline & M-63 & dd, deg & $0 \ldots 360$ & $\pm 10^{\circ}$ & $1 \mathrm{~s}$ \\
\hline & M-63 & $V, \mathrm{~ms}^{-1}$ & $1.2 \ldots 40$ & $\pm(0.5+0.05 \mathrm{~V})$ & $1 \mathrm{~s}$ \\
\hline & MPX4115AP & $P, \mathrm{hPa}$ & $150 \ldots 1150$ & \pm 1.5 & $0.001 \mathrm{~s}$ \\
\hline \multirow[t]{8}{*}{ Gas analyzer } & G2301-m & $\mathrm{CO}_{2}, \mathrm{ppm}$ & $0 \ldots 1000$ & $<0.2 \mathrm{ppm}$ & $1 \mathrm{~s}$ \\
\hline & & $\mathrm{CH}_{4}, \mathrm{ppm}$ & $0 \ldots 20$ & $<0.0015 \mathrm{ppm}$ & $1 \mathrm{~s}$ \\
\hline & & $\mathrm{H}_{2} \mathrm{O}, \mathrm{ppm}$ & $0 \ldots 70000$ & $<150 \mathrm{ppm}$ & $1 \mathrm{~s}$ \\
\hline & 3.02-П & $\mathrm{O}_{3}, \mu \mathrm{g} \mathrm{m}^{-3}$ & $0 \ldots 500$ & $\pm 20 \%$ & $1 \mathrm{~s}$ \\
\hline & P-310 & $\mathrm{NO} / \mathrm{NO}_{2}, \mu \mathrm{g} \mathrm{m}^{-3}$ & $0 \ldots 1000$ & $\pm 25 \%$ & $160 \mathrm{~s}$ \\
\hline & $\mathrm{K}-100$ & $\mathrm{CO}, \mathrm{mg} \mathrm{m}^{-3}$ & $0 \ldots 50$ & $\pm 20 \%$ & $1 \mathrm{~s}$ \\
\hline & API 100E & $\mathrm{SO}_{2}, \mathrm{ppm}$ & $0 \ldots 20$ & $\pm 0.5 \%$ & $20 \mathrm{~s}$ \\
\hline & Brewer 049 & $\mathrm{TO}, \mathrm{DU}$ & - & $\pm 1 \%$ & $120 \mathrm{~s}$ \\
\hline \multirow[t]{4}{*}{ Aerosol system } & GRIMM 1.109 & $D_{\mathrm{p}}, \mu \mathrm{m}$ (31 channels) & $0.25 \ldots 32$ & - & $6 s$ \\
\hline & & $N, \mathrm{~cm}^{-3}$ & $0 \ldots 2000$ & $\pm 3 \%$ & \\
\hline & Diffusion aerosol & $D_{\mathrm{p}}, \mathrm{nm}$ (20 channels) & $3 \ldots 200$ & - & $80 \mathrm{~s}$ \\
\hline & spectrometer & $N, \mathrm{~cm}^{-3}$ & $0 \ldots 500000$ & $\pm 10 \%$ & \\
\hline Air ions & Sapfir-3M & $N, \mathrm{~cm}^{-3}$ & $0 \ldots 2500000$ & $\pm 5 \%$ & $4 \mathrm{~s}$ \\
\hline \multirow{6}{*}{ Radiation unit } & M-115 & $\lambda, \mu \mathrm{m}$ & $0,3 \ldots 2,4$ & $\pm 10 \%$ & $<40 \mathrm{~s}$ \\
\hline & & $Q, \mathrm{~W} \mathrm{~m}^{-2}$ & $0 \ldots 1500$ & & \\
\hline & YES UVB-1 & $\lambda, \mathrm{nm}$ & $280 \ldots 320$ & - & $0.1 \mathrm{~s}$ \\
\hline & & $I, \mathrm{~W} \mathrm{~m}^{-2}$ & $0 \ldots 2.5$ & $<5 \%$ & \\
\hline & Brewer 049 & $\lambda, \mathrm{nm}$ & $290 \ldots 325$ & - & $265 \mathrm{~s}$ \\
\hline & & $I, \mathrm{~W} \mathrm{~m}^{-2}$ & - & - & \\
\hline \multirow[t]{2}{*}{$\begin{array}{l}\text { Gamma } \\
\text { background }\end{array}$} & IRF & $\gamma$-background, $\mu R \mathrm{~h}^{-1}$ & $1 \ldots 1000$ & $30 \%$ & $1 \mathrm{~s}$ \\
\hline & \multicolumn{5}{|c|}{ BEC } \\
\hline Unit & Device/sensor & Parameter & Range & Error & Time constant \\
\hline \multirow[t]{5}{*}{ Weather station } & HIH-3602-C & $T,{ }^{\circ} \mathrm{C}$ & $-40 \ldots+85$ & $\pm 0.1^{\circ} \mathrm{C}$ & $1 \mathrm{~s}$ \\
\hline & HIH-3602-C & $U, \%$ & $0 \ldots 100$ & $\pm 2 \%$ & $1 \mathrm{~s}$ \\
\hline & M-63 & dd, deg & $0 \ldots 360$ & $\pm 10^{\circ}$ & $1 \mathrm{~s}$ \\
\hline & M-63 & $V, \mathrm{~ms}^{-1}$ & $1,2 \ldots 40$ & $\pm(0.5+0.05 \mathrm{~V})$ & $1 \mathrm{~s}$ \\
\hline & MPX4115AP & $P, \mathrm{hPa}$ & $150 \ldots 1150$ & \pm 1.5 & $0.001 \mathrm{~s}$ \\
\hline \multirow[t]{6}{*}{ Gas analyzer } & LI-820 & $\mathrm{CO}_{2}, \mathrm{ppm}$ & $0 \ldots 1000$ & $<0.2^{*} \mathrm{ppm}$ & $1 \mathrm{~s}$ \\
\hline & 3.02-П & $\mathrm{O}_{3}, \mu \mathrm{g} \mathrm{m}^{-3}$ & $0 \ldots 500$ & $\pm 20 \%$ & $1 \mathrm{~s}$ \\
\hline & API $200 \mathrm{E}$ & $\mathrm{NO} / \mathrm{NO}_{2}, \mathrm{ppm}$ & $0 \ldots 20$ & $\pm 0.5 \%$ & $20 \mathrm{~s}$ \\
\hline & $\mathrm{K}-100$ & $\mathrm{CO}, \mathrm{mg} \mathrm{m}^{-3}$ & $0 \ldots 50$ & $\pm 20 \%$ & $1 \mathrm{~s}$ \\
\hline & ME 9850B & $\mathrm{SO}_{2}, \mathrm{ppm}$ & $0 \ldots 20$ & $\pm 1 \%$ & $<20 \mathrm{~s}$ \\
\hline & HCNM 2000G & $\mathrm{CH}_{4}$ and $\Sigma \mathrm{CH}, \mathrm{ppm}$ & $0 \ldots 10$ & 0.1 & $120 \mathrm{~s}$ \\
\hline \multirow[t]{2}{*}{ Aerosol system } & GRIMM 1.108 & $D_{\mathrm{p}}, \mu \mathrm{m}$ (15 channels $)$ & $0.3 \ldots 20$ & - & $6 \mathrm{~s}$ \\
\hline & & $N, \mathrm{~cm}^{-3}$ & $0 \ldots 2000$ & $\pm 3 \%$ & \\
\hline \multicolumn{6}{|c|}{ Fonovaya Observatory } \\
\hline Unit & Device/sensor & Parameter & Range & Error & Time constant \\
\hline \multirow[t]{5}{*}{ Weather station } & HIH-3602-C & $T,{ }^{\circ} \mathrm{C}$ & $-40 \ldots+85$ & $\pm 0.1^{\circ} \mathrm{C}$ & $1 \mathrm{~s}$ \\
\hline & HIH-3602-C & $U, \%$ & $0 \ldots 100$ & $\pm 2 \%$ & $1 \mathrm{~s}$ \\
\hline & M-63 & dd, deg & $0 \ldots 360$ & $\pm 10^{\circ}$ & $1 \mathrm{~s}$ \\
\hline & M-63 & $V, \mathrm{~m} \mathrm{~s}^{-1}$ & $1.2 \ldots 40$ & $\pm(0.5+0.05 \mathrm{~V})$ & $1 \mathrm{~s}$ \\
\hline & MPX4115AP & $P, \mathrm{hPa}$ & $150 \ldots 1150$ & \pm 1.5 & $0.001 \mathrm{~s}$ \\
\hline \multirow[t]{8}{*}{ Gas analyzer } & FGGA & $\mathrm{CO}_{2}, \mathrm{ppm}$ & $20 \ldots 10000$ & $0.2 \mathrm{ppm}$ & $1 \mathrm{~s}$ \\
\hline & model 907-0010 & $\mathrm{CH}_{4}, \mathrm{ppm}$ & $0.005 \ldots 50$ & $0.001 \mathrm{ppm}$ & \\
\hline & & $\mathrm{H}_{2} \mathrm{O}, \mathrm{ppm}$ & $150 \ldots 70000$ & $100 \mathrm{ppm}$ & \\
\hline & LI-840 & $\mathrm{CO}_{2}, \mathrm{ppm}$ & $0 \ldots 1000$ & $<0.2^{*} \mathrm{ppm}$ & $1 \mathrm{~s}$ \\
\hline & 3.02-P & $\mathrm{O}_{3}, \mu \mathrm{g} \mathrm{m}^{-3}$ & $0 \ldots 500$ & $\pm 20 \%$ & $1 \mathrm{~s}$ \\
\hline & P-310 & $\mathrm{NO} / \mathrm{NO}_{2}, \mu \mathrm{g} \mathrm{m}^{-3}$ & $0 \ldots 1000$ & $\pm 25 \%$ & $160 \mathrm{~s}$ \\
\hline & $\mathrm{K}-100$ & $\mathrm{CO}, \mathrm{mg} \mathrm{m}^{-3}$ & $0 \ldots 50$ & $\pm 20 \%$ & $1 \mathrm{~s}$ \\
\hline & P-310 & $\mathrm{SO}_{2}, \mathrm{mg} \mathrm{m}^{-3}$ & $0 \ldots 2$ & $\pm 25 \%$ & $142 \mathrm{~s}$ \\
\hline \multirow[t]{4}{*}{ Aerosol system } & GRIMM 1.108 & $D_{\mathrm{p}}, \mu \mathrm{m}$ (15 channels $)$ & $0,3 \ldots 20$ & - & $6 \mathrm{~s}$ \\
\hline & & $N, \mathrm{~cm}^{-3}$ & $0 \ldots 2000$ & $\pm 3 \%$ & \\
\hline & Diffusion aerosol spec- & $D_{\mathrm{p}}, \mathrm{nm}(20$ channels $)$ & $3 \ldots 200$ & - & $160 \mathrm{~s}$ \\
\hline & trometer & $N, \mathrm{~cm}^{-3}$ & $0 \ldots 1000000$ & $\pm 10 \%$ & \\
\hline Air ions & Sapfir $-3 \mathrm{M}$ & $N, \mathrm{~cm}^{-3}$ & $0 \ldots 2500000$ & $\pm 5 \%$ & $4 \mathrm{~s}$ \\
\hline
\end{tabular}

* at calibration against control gas mixtures 
differential aethalometer developed at IAO SB RAS (Kozlov et al., 2008b). The concentration sensitivity of the aethalometer is about $10 \mathrm{ng} \mathrm{m}^{-3}$ at $30 \mathrm{~L}$ of air pumped through it. The aethalometer has been calibrated under laboratory conditions with the help of a pyrolysis generator of soot (black carbon) particles and the comparison of data of synchronous optical and gravimetric measurements.

An aureole photometer measures the directed scattering coefficient in the angular range $1.2-20^{\circ}$ and is used for estimation of the mass content of coarse particles in the size spectrum (Shmargunov et al., 2010).

The system of active polarization nephelometry, which is also used at the aerosol station, includes the FAN nephelometer and devices for artificial humidification of aerosol up to $90 \%$ relative humidity of air or for heating up to $250^{\circ} \mathrm{C}$. It serves for the measurement of aerosol hygro- and thermograms, which are used for determination of the parameter of hygroscopic activity of particles and the fractional content of volatile compounds in aerosol. Polarization measurements with this system allow the microstructure and optical constants of submicron aerosol particles to be determined through solution of the inverse problem.

Remote laser sensing of aerosol fields in the troposphere was carried out with the stationary multifrequency LOZA lidar at three laser wavelengths of 355, 532, and $1064 \mathrm{~nm}$ with laser pulse repetition frequency of $20 \mathrm{~Hz}$ and pulse length of $10 \mathrm{~ns}$. The lidar system detects not only echo signals of elastic backscattering but also signals of Raman scattering by molecular nitrogen (387 and $607 \mathrm{~nm}$ ) and water vapor $(407 \mathrm{~nm})$ at the same wavelengths in nighttime. Polarization components of backscattered radiation at a wavelength of $532 \mathrm{~nm}$ were measured in an additional channel. The multifrequency lidar provides retrieval of high-quality information about the vertical (from the surface to the lower stratosphere) distribution of optical (scattering and extinction coefficients, optical depth) and microphysical (nonsphericity, phase composition, mean size spectrum of aerosol particles within the identified layer) properties of aerosol. More detailed description of the lidar and methods for optical parameters retrieve see in Samoilova et al. (2009).

For monitoring the temperature, humidity, ozone, aerosol, and clouds with a spatial resolution of $1-10 \mathrm{~km}$, the data from a MODIS multichannel spectroradiometer (spectral range 0.4-14 $\mu \mathrm{m}$ ) installed on Terra and Aqua platforms of the EOS satellite system were mostly used.

The sounding of MGCs from space was carried out with the MetOP-A satellite IASI (Infrared Atmospheric Sounding Interferometer) Fourier spectrometer with a spectral resolution of $0.35-0.5 \mathrm{~cm}^{-1}$ in the range $645-2760 \mathrm{~cm}^{-1}$ and a spatial resolution from 25 to $100 \mathrm{~km}$ depending on MGC. In addition to the IASI data, the data from the Aqua AIRS (Atmospheric Infrared Sounder) with nominal spatial resolution of $\sim 45 \mathrm{~km}$ and spectral resolution $\lambda / \Delta \lambda \sim 1200$ in 2378 channels lying in the ranges 3.74 $4.61 \mu \mathrm{m}, 6.20-8.22 \mu \mathrm{m}$, and $8.80-15.40 \mu \mathrm{m}$ were used for the same purposes. The information about satellite dish can be found on http://www.orbitalsystems.com/antenna-products/ systems/eosdb-systems.

The measurement system includes facilities for local and remote acoustic diagnostics of the atmospheric boundary layer, namely, METEO-2 Ultrasonic Meteostations (UMSs) (Gladkikh and Makienko, 2009) and VOLNA-4 threechannel acoustic Doppler sodar, whose main operating principles and some results are described in Gladkikh et al. (1999, 2009) and Odintsov and Fedorov (2007).

Starting from January 1996, an automated spectrophotometer installed at the Siberian lidar station (SLS) of IAO SB RAS carries out regular measurements of atmospheric $\mathrm{NO}_{2}$ (nitrogen dioxide is a component of the nitrogen catalytic cycle of ozone destruction). The spectrophotometer records the spectrum of solar radiation scattered at zenith in the wavelength range $430-450 \mathrm{~nm}$ in twilight periods, when the solar zenith angle varies from 83 to $96^{\circ}$. The slant $\mathrm{NO}_{2}$ content along the trajectory of recorded radiation is calculated from the deformation of the spectrum. The data on the slant $\mathrm{NO}_{2}$ content in the atmosphere are used to retrieve, through solution of the inverse problem, the vertical distribution of $\mathrm{NO}_{2}$ in 10 layers, each $5 \mathrm{~km}$ thick in the altitude range from 0 to $50 \mathrm{~km}$. Then the total $\mathrm{NO}_{2}$ content is calculated as a sum over all the layers.

To study fluctuation parameters of the atmosphere, a multiparameter instrument has been designed. It is intended for automated measurements of wind speed pulsations, temperature, humidity, and the coefficient of angular aerosol light scattering in the surface air layer.

The instrument is a portable automatic device, comprising an acoustic meter of three wind velocity components and virtual temperature; an optical infrared meter of micropulsations of absolute humidity; temperature, pressure, and relative humidity sensors; and an open-type single-angle nephelometer for measuring pulsations of aerosol scattering coefficient and estimating pulsations of the atmospheric aerosol concentration. Measurements of dynamic and thermodynamic characteristics of turbulence are accompanied by measurements of solar radiation; i.e., the instrument comprises sensors of incoming and outgoing solar radiation in the visible spectral range. The temperature, humidity, wind velocity, and aerosol fields are studied to different extents; the pulsations are measured by different methods and in different periods of time. Hence, the data of these measurements are often incomparable. Therefore, the direct pulsation measurements are still urgent in the context of refinement of turbulence parameters. The instrument consists of three main spatially localized parts: modernized version of three-component ultrasonic anemometer-thermometer, spectroscopic meter of absolute humidity, and open-type nephelometer.

The developed measurement system allows one to retrieve the whole set of microphysical, chemical, and optical aerosol parameters from data measured. 


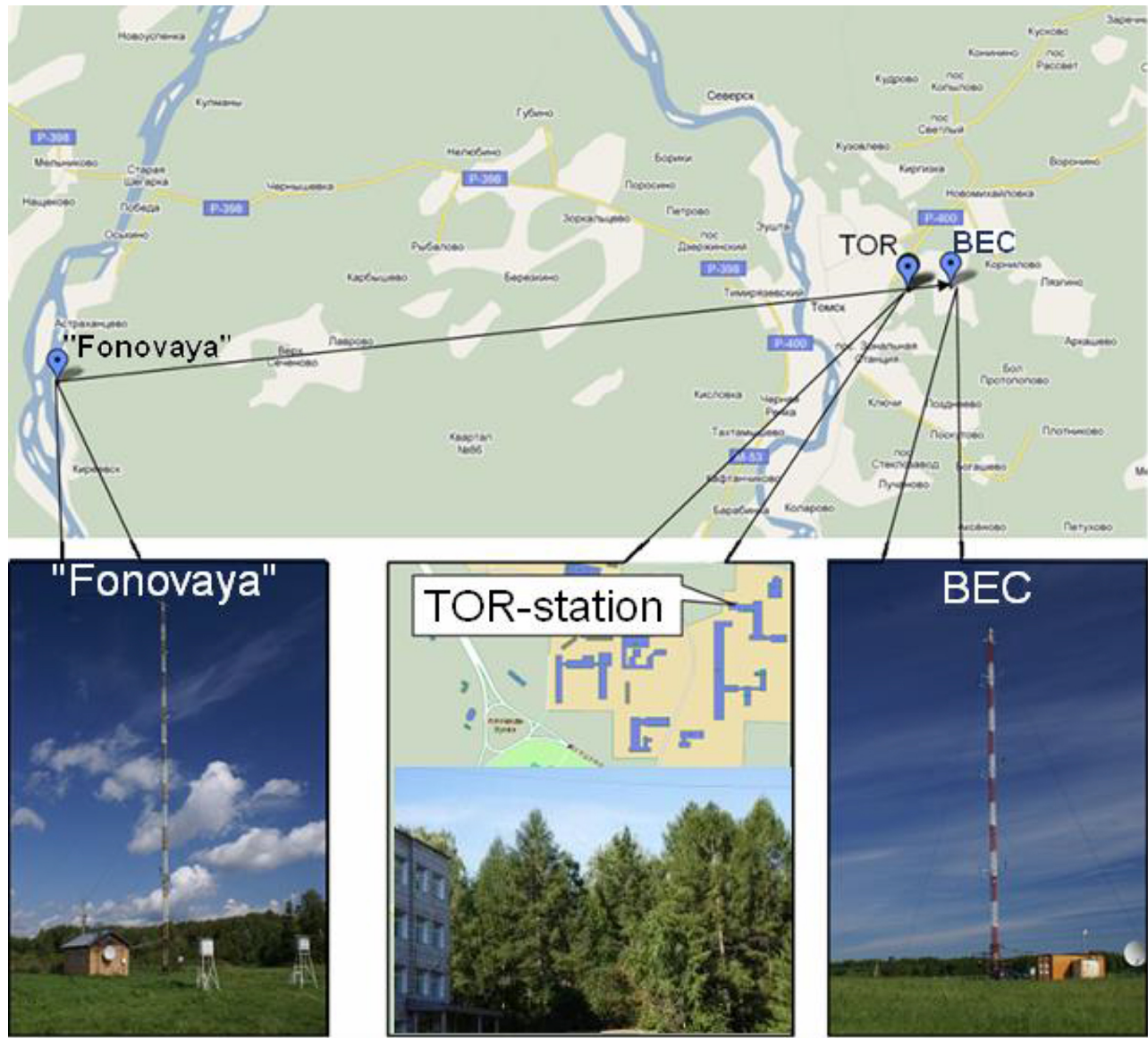

Figure 2. Arrangement of stations for atmospheric monitoring.

\section{Measuring sites}

Concentrations of MGCs were routinely measured at three IAO SB RAS monitoring stations (Fig. 2): Fonovaya Observatory, TOR Station, and Basic Experimental Complex. The Fonovaya Observatory is located $70 \mathrm{~km}$ to the west of Tomsk, the TOR station is situated at the northeastern end of the Tomsk Scientific Center (Akademgorodok), and BEC is located in suburbs $3 \mathrm{~km}$ to the east from Akademgorodok (Table 3). This arrangement of the stations (nearly in line) in the case of the west-eastern air mass transport allows us to estimate the anthropogenic contribution of Tomsk to the formation of the field of atmospheric pollutants.

The vertical distribution of the climatically significant components of the troposphere was studied with the Tu-134 OPTIK flying laboratory.

Within the complex aerosol experiment, the Tu-134 OPTIK flying laboratory carried out a sounding flight over the territory of the Ob-Tom interfluve, southwest of Tomsk (on the Kozhevnikovo-Kurlek traverse) on 9 April 2013, with the use of instruments for remote sounding and local control. The flight trajectory is shown in Figs. 3 and 4 below.
The temperature-wind sounding was carried out with the Vaisala R92SGP radiosonde.

The atmospheric AOD was monitored (in particular on 22 May 2012) at two observation sites: in Tomsk (IAO SB RAS) and at the Fonovaya Observatory.

At the stationary Aerosol Station of IAO SB RAS located at the southeastern end of Tomsk (http://aerosol.iao. $\mathrm{ru} /$ ?lang=en; $56.5^{\circ} \mathrm{N}, 85.1^{\circ} \mathrm{E}$; GMT + 7.00), surface aerosol parameters were monitored every hour around the clock. The complex aerosol experiment in 2013 included a cycle of simultaneous two-site measurements at the IAO Aerosol Station in Tomsk and at the mobile Aerosol Station based at the Fonovaya Observatory in the forest zone $70 \mathrm{~km}$ to the west from Tomsk. The mass concentrations of aerosol and black carbon were measured every hour around the clock at the two measuring sites.

Aerosol fields of the troposphere were sensed with the LOZA-S stationary multifrequency lidar, continuously from 06:00 local time to 20:00 in 2013.

In 2013, the two-site radiative experiment was conducted in Tomsk and at the Fonovaya Observatory. This experiment invoked the data of a MODIS multichannel spectroradiome- 


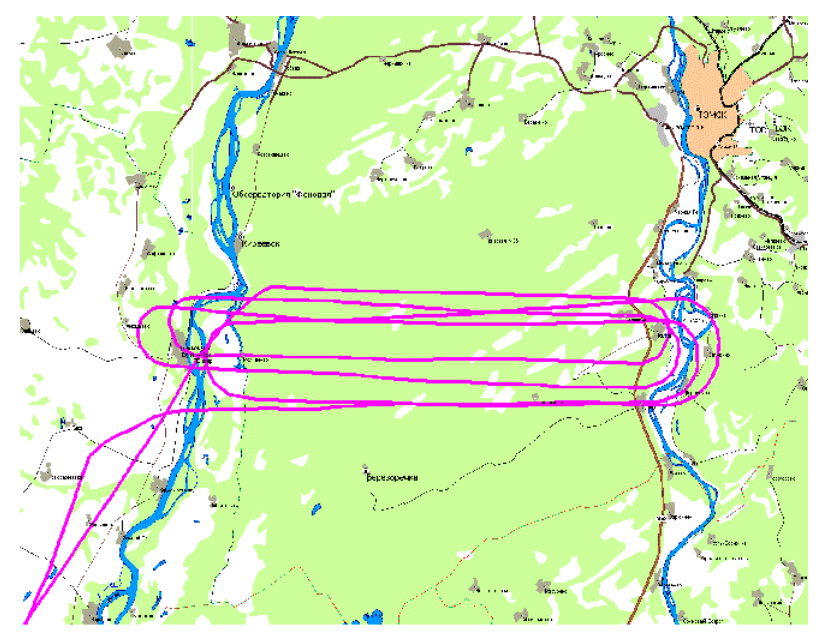

Figure 3. Flight trajectory of the Tu-134 OPTIK flying laboratory on 9 April 2013.

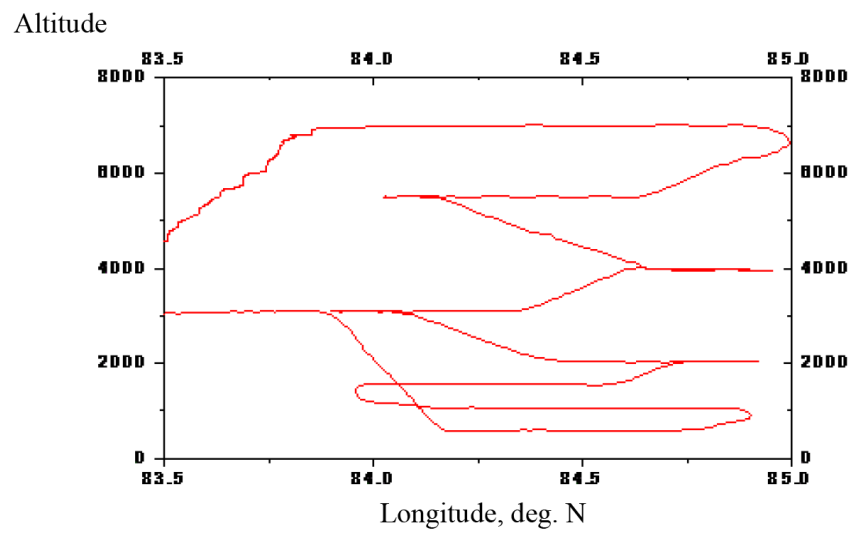

Figure 4. Altitude profile of the flight of the Tu-134 OPTIK flying laboratory on 9 April 2013.

ter installed on Terra and Aqua platforms of the EOS satellite system.

The acoustic diagnostics of the atmospheric boundary layer has been carried out with the use of local and remote facilities within the complex aerosol experiment. Local facilities - METEO-2 USMs - were installed at the territory of the Fonovaya Observatory IAO SB RAS (Kireevsk) and in Tomsk on the roof of the laboratory building of IAO SB RAS. METEO-2 USMs operated around the clock in the permanent mode to measure mean values and turbulent characteristics of wind, air temperature, static atmospheric pressure, and relative air humidity. The sodar operated every day from 08:00 to 21:00 LT and measured the height of the intense turbulent heat exchange layer and wind vector components in this layer (height range from 50 to $700 \mathrm{~m}$ ).

At the IAO SLS located in Tomsk $\left(56.5^{\circ} \mathrm{N}, 85.0^{\circ} \mathrm{E}\right)$, the automated spectrophotometer measured the nitrogen dioxide
Table 3. Coordinates of the stations.

\begin{tabular}{llll}
\hline Station & Latitude & Longitude & $\begin{array}{l}\text { Altitude above } \\
\text { mean sea level }\end{array}$ \\
\hline TOR & $56^{\circ} 28 / 41 \prime \prime$ & $85^{\circ} 03 / 15 \prime \prime$ & 133 \\
Fonovaya 1 & $56^{\circ} 25 / 07 \prime \prime$ & $84^{\circ} 04 / 27 \prime \prime$ & 80 \\
BEC & $56^{\circ} 28 / 49 \prime \prime$ & $85^{\circ} 06 / 08 \prime \prime$ & 120 \\
\hline
\end{tabular}

concentration in the atmosphere during morning and evening twilight.

Thus, the whole set of microphysical, chemical, and optical characteristics of aerosol in Southwestern Siberia was studied simultaneously during the complex aerosol experiment (2013) with the use of the unique measurement system including ground-based, airborne, and spaceborne measurement facilities.

\section{Results of complex aerosol experiment}

The experiment provided sun photometer measurements of AOD, acoustic sounding of the boundary layer, laser sensing of aerosol content in the troposphere and stratosphere, measurements of the gaseous composition of the atmosphere (including greenhouse gases), and measurements of meteorological parameters of air, including with the help of weather balloons.

The vertical aerosol and black carbon profiles were measured onboard the aircraft on 9 April (during flights near Tomsk and Zavyalovo settlement and in the south of Novosibirsk region), 30 July (Zavyalovo settlement), and 1 October 2013 (Tomsk and Zavyalovo settlement), as shown in Fig. 5a, b, and c, respectively.

The measurement data show that aerosol and black carbon profiles are close in shape and agree with specific features of vertical variations which we have revealed earlier. Figure 5a shows the vertical profiles of the mass concentrations of aerosol and black carbon in spring. The columnar concentrations determined from these profiles are close to the springtime average values of 1.64 and $0.18 \mathrm{mg} \mathrm{m}^{-2}$ for aerosol and black carbon, respectively, which we found earlier from results of regular aircraft measurements in the south of Western Siberia in 1999-2011 under clear-sky conditions. This finding is consistent with the fact that measurements on 9 April near Tomsk were performed under the solar weather at a cloud amount of about 3, i.e., in the low-cloud atmosphere.

Figure $5 \mathrm{~b}$ shows the altitude profiles of the parameters under study for the flight on 30 July 2013 in the region of Zavyalovo settlement. It is clearly seen that high aerosol and black carbon levels were observed at all altitudes in this time, primarily due to the effect of forest fire smoke plumes. The aerosol concentrations in the surface air layer were higher than $100 \mu \mathrm{g} \mathrm{m}^{-3}$, and black carbon concentrations attained 


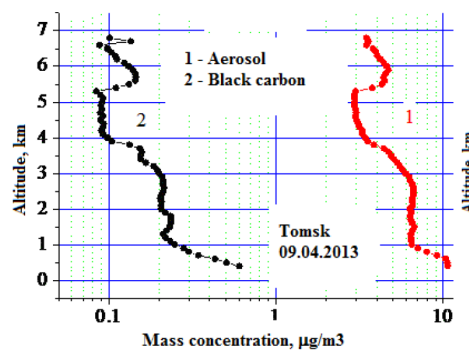

a)

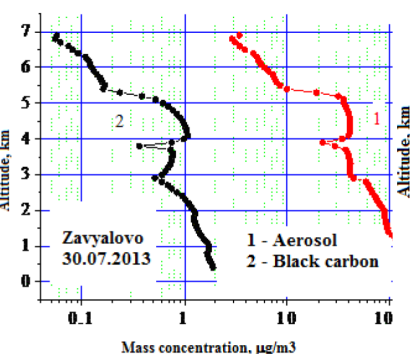

b)

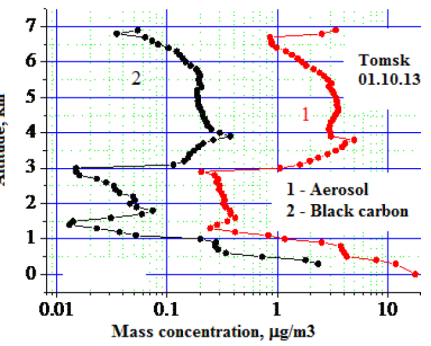

c)

Figure 5. Vertical aerosol and black carbon profiles from flying laboratory data in the Tomsk region for (a) 9 April (near Tomsk and Zavyalovo settlement, south of Novosibirsk region), (b) 30 July (Zavyalovo settlement), and (c) 1 October 2013 (Tomsk and Zavyalovo settlement).

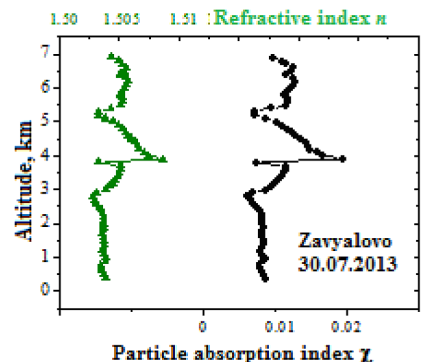

a)

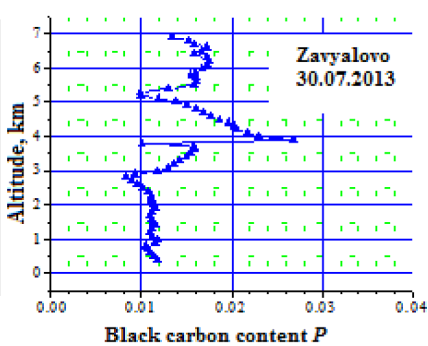

b)
Figure 6. Altitude profiles of (a) refractive and absorption indices of dry aerosol base and (b) relative black carbon content during the flight on 30 July 2013 in the region of Zavyalovo settlement.

$2 \mu \mathrm{g} \mathrm{m}^{-3}$, a factor of 3-4 higher than the mean background summertime concentrations. Thus, this flight was actually performed in the smoky atmosphere. The total black carbon column explicitly attained levels of high smoke content of the atmosphere of about $6 \mathrm{mg} \mathrm{m}^{-2}$, the AOD value being 1.45. Correspondingly, the smoke conditions were characterized by low particle absorption index $\chi$ (Fig. 6a) and relative black carbon content $P<0.02$ (Fig. 6b).

Figure 5c shows the altitude profiles of the aerosol parameters under study in two regions in autumn, on 1 October 2013. Analysis of meteorological conditions during the flight showed that the preceding days were characterized by stable cloudy weather with rains and overcast cumulus clouds. The weather became better on the day of the flight, and sometimes the sun was seen through the gaps; however, a few layers of diffused clouds were recorded during the flight. The presence of clouds influenced the vertical stratification of aerosol; as a consequence, the altitude profiles show the presence of two-level clouds and increased altitude variations. The total black carbon column and AOD somewhat differ from autumn average background values of $1.26 \mathrm{mg} \mathrm{m}^{-2}$ and 0.094 , respectively.

Analysis of near-ground measurements at the IAO SB RAS aerosol station showed that variations in the aerosol parameters qualitatively agree with aircraft measurement re-

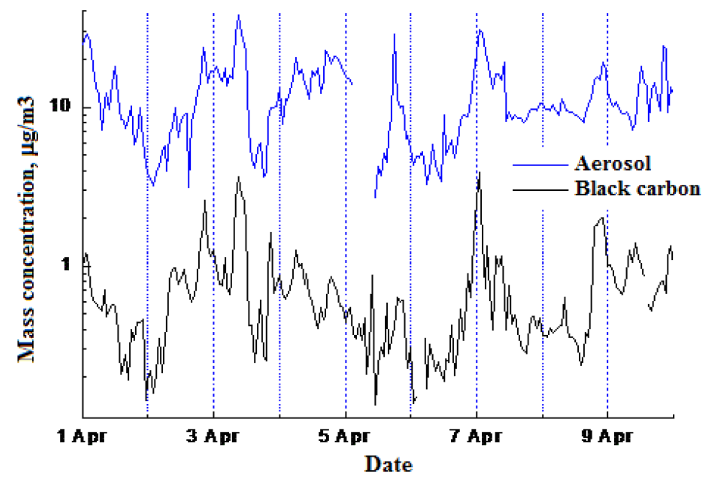

Figure 7. Time variations in the mass concentrations of dry base of submicron aerosol and black carbon during 1-9 April 2013.

sults (Figs. 7-8). The analysis was performed using daily average variations in the dry bases of submicron aerosol and in black carbon normalized to their daily average values (Fig. 7). The daily variations in the condensation activity parameter $\gamma$ exhibits anticorrelation with the variations in the mass concentrations of submicron aerosol and black carbon (Fig. 8).

To date, the arrays of data on aerosol number density from the TOR station and Fonovaya Observatory include over 1900000 and 410000 measurements, respectively. The maximal concentrations, observed at both stations, were tens of thousands of particles per $\mathrm{cm}^{3}$. The decade average values of the total number density ranged from $1.3 \times 10^{3}$ to $1.2 \times 10^{4} \mathrm{~cm}^{-3}$ at the TOR station and from $1.4 \times 10^{3}$ to $5.8 \times 10^{3} \mathrm{~cm}^{-3}$ near the observatory. The average aerosol number density over the entire period of observations was $4890 \mathrm{~cm}^{-3}\left( \pm 4905 \mathrm{~cm}^{-3}\right.$, median $\left.=3610 \mathrm{~cm}^{-3}\right)$ at the TOR station and $3200 \mathrm{~cm}^{-3}\left( \pm 3244 \mathrm{~cm}^{-3}\right.$, median $\left.=2561 \mathrm{~cm}^{-3}\right)$ at the Fonovaya Observatory.

The data set accumulated allows us to classify the diurnal dynamics of aerosol number density in the atmosphere of the boreal zone of Western Siberia and to obtain the statistics on frequency of nucleation surges (NSs). Nucleation per se cannot be recorded by present-day methods, because the 


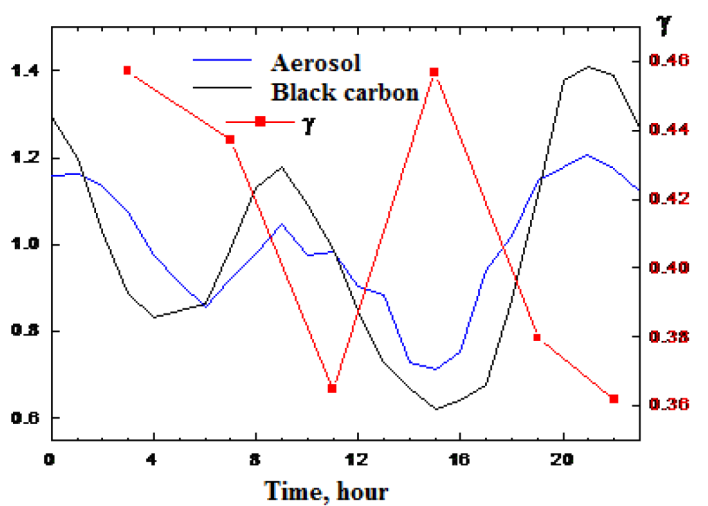

Figure 8. Normalized daily average variations in the mass concentrations of dry base of submicron aerosol and black carbon, smoothed using three-point moving average, and daily average variations in the condensation activity parameter during 1-9 April 2013.

detection limit of most condensation particle counters is 2$10 \mathrm{~nm}$. However, considering that formation of nucleationmode particles is associated with growth of stable clusters formed from the nucleation, surges in the nanoparticle formation henceforth will be called NSs.

All days of observations were divided into three main groups: (1) nanoparticle formation event; (2) uncertain type and no in situ particle formation, i.e., when the nucleation mode was not clearly traced throughout a day; and (3) predominately bimodal total number density of particles (Aitken mode + accumulation mode).

After the particle formation events had been chosen, they were subdivided into three types. Type 1 is characterized by high concentrations of formed nucleation-mode particles $\left(D_{\mathrm{p}}<16 \mathrm{~nm}\right)$ and a low concentration of coarse particles in the atmosphere. Type 1 reflects events of intense and well pronounced formation of the smallest particles, accompanied by continuous growth of the particles during $7-10 \mathrm{~h}$.

Type 2 events are characterized by the behavior similar to Type 1 events but weaker pronounced; i.e., there are single fluctuations in the size distribution, but the features of formation and further particle growth, lasting a little shorter $(<5 \mathrm{~h})$ than Type 1 events, are rather well discernible. Despite these differences, the formation and growth rates can be calculated for these both types at a reasonable level of confidence.

Type 3 includes events with certain signs of new particle formation, but one of the stages is not very well discernible. These may be cases, e.g., where the process of particle formation and growth, once initiated, could then be interrupted due to effects of a number of factors, such as cloud-caused sharp decrease in the solar radiation, air mass change (frontal passage), rain, etc. Type 3 also includes cases with weak or ill-defined particle growth.

In all, 1186 days were analyzed at the TOR station from 4 March 2010 to 30 September 2013, inclusive, and 732 days were analyzed on the territory of Fonovaya Observatory from
Table 4. Total number of days when nanoparticles formed in situ (Types 1, 2, and 3), type was uncertain (Type 0), and no nucleation (Type 4) was observed over the entire measurement period. ND means no data available, i.e., days when the instrumentation did not work for any reasons; TND means the total number of days analyzed.

\begin{tabular}{|c|c|c|c|c|c|c|c|}
\hline \multicolumn{8}{|c|}{ TOR station } \\
\hline Month & Type 1 & Type 2 & Type 3 & Type 0 & Type 4 & ND & TND \\
\hline 1 & 1 & 1 & 5 & 11 & 69 & 6 & 87 \\
\hline 2 & 3 & 2 & 4 & 10 & 63 & 3 & 82 \\
\hline 3 & 20 & 20 & 9 & 23 & 40 & 12 & 112 \\
\hline 4 & 30 & 11 & 7 & 21 & 31 & 20 & 100 \\
\hline 5 & 15 & 19 & 6 & 28 & 52 & 4 & 120 \\
\hline 6 & 3 & 6 & 15 & 18 & 63 & 13 & 105 \\
\hline 7 & 2 & 10 & 6 & 22 & 58 & 26 & 98 \\
\hline 8 & 7 & 12 & 7 & 24 & 66 & 8 & 116 \\
\hline 9 & 17 & 11 & 7 & 18 & 64 & 3 & 117 \\
\hline 10 & 7 & 6 & 3 & 13 & 58 & 6 & 87 \\
\hline 11 & 2 & 2 & 0 & 5 & 66 & 15 & 75 \\
\hline 12 & 2 & 2 & 3 & 5 & 75 & 6 & 87 \\
\hline Total & 109 & 102 & 72 & 198 & 705 & 122 & 1186 \\
\hline \multicolumn{8}{|c|}{ Fonofaya Observatory } \\
\hline Month & Type 1 & Type 2 & Type 3 & Type 0 & Type 4 & ND & TND \\
\hline 1 & 0 & 1 & 4 & 5 & 46 & 6 & 56 \\
\hline 2 & 4 & 1 & 7 & 9 & 36 & 0 & 57 \\
\hline 3 & 7 & 5 & 5 & 6 & 25 & 14 & 48 \\
\hline 4 & 10 & 11 & 9 & 5 & 20 & 5 & 55 \\
\hline 5 & 3 & 5 & 8 & 5 & 31 & 41 & 52 \\
\hline 6 & 2 & 2 & 6 & 9 & 53 & 18 & 72 \\
\hline 7 & 1 & 4 & 3 & 5 & 60 & 20 & 73 \\
\hline 8 & 3 & 4 & 6 & 5 & 66 & 9 & 84 \\
\hline 9 & 17 & 8 & 6 & 7 & 39 & 13 & 77 \\
\hline 10 & 5 & 3 & 0 & 3 & 44 & 7 & 55 \\
\hline 11 & 1 & 0 & 6 & 3 & 43 & 7 & 53 \\
\hline 12 & 0 & 0 & 1 & 4 & 45 & 12 & 50 \\
\hline Total & 53 & 44 & 61 & 66 & 508 & 152 & 732 \\
\hline
\end{tabular}

13 May 2011 to 30 September 2013, thus covering 91 and $83 \%$ of the entire period of observations, respectively. Table 4 summarizes the general information on the number of days classified at both sites. Among the total number of days (TND) when the instrumentation operated normally, 283 events of NSs (Type $1+2+3 ; 23.9 \%$ ), 705 days with no in situ aerosol formation (Type 4; 59.4\%), and 198 uncertain cases (Type $0 ; 16.7 \%$ ) were identified at the TOR station.

Despite the shorter data record from the Fonovaya Observatory, the total frequency of surges (percent) is comparable with the data from the TOR station: $158(21.6 \%), 508$ $(69.4 \%)$, and $(9.0 \%)$, respectively. The differences are primarily explained by different numbers of days of the uncertain type. If they are excluded from the analysis (by subtracting Type 0 days from TND), the differences between the frequencies of non-occurrence of NS events (Type 4) decrease to 71.4 and $76.3 \%$ at the TOR station and Fonovaya observatory, respectively. At the same time, the percentage of the NS events somewhat increases, to $28.6 \%$ at the TOR station and $23.7 \%$ in the region of Fonovaya Observatory. 

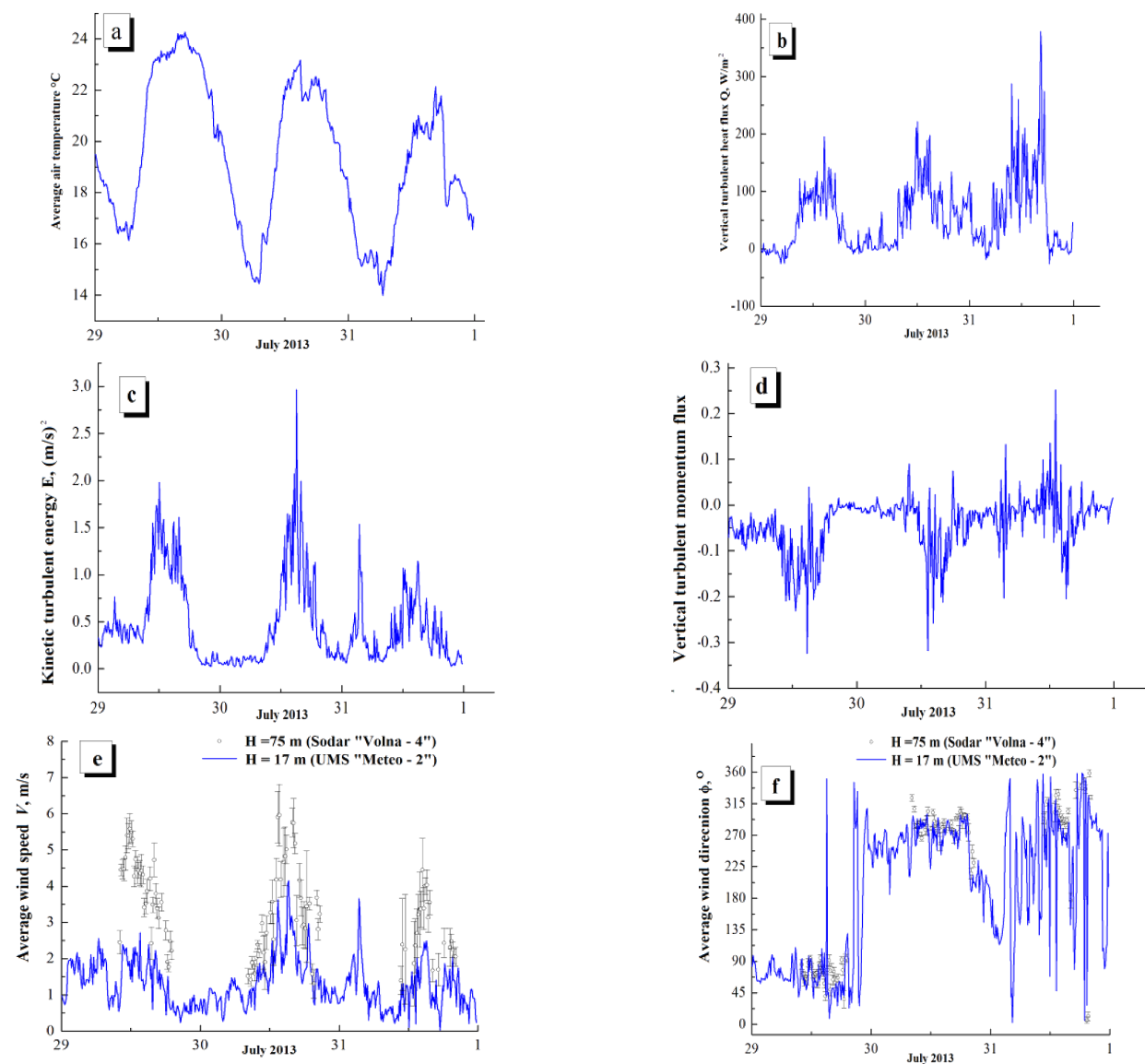

Figure 9. Time variations in the (a) air temperature, (b) vertical turbulent heat flux, (c) kinetic turbulent energy, (d) vertical turbulent momentum flux, and wind (e) speed and (f) direction at an altitude of $17 \mathrm{~m}$ during the first cycle of measurements. The circles (e and f) show the wind speed and direction (with $90 \%$ confidence intervals) at an altitude of $50 \mathrm{~m}$.

As an example, Fig. 9 shows some results of acoustical diagnostics of meteorological parameters of the surface air layer for each measurement cycle (10 min estimation interval):

- average air temperature $T^{\circ} \mathrm{C}$;

- vertical turbulent heat flux;

- total turbulent kinetic energy;

- vertical turbulent momentum flux (normalized to $\bar{\rho}$ );

- average wind speed $V_{h}$ and direction $\phi$.

It should be noted that the database compiled contains a larger set of average meteorological parameters and turbulence characteristics than shown in Fig. 9. In addition, the available archive of raw experimental data permits us, if necessary, to calculate many other turbulence characteristics, which are absent in the database compiled.

The time variations in the spectral AOD, Ångström exponent $\alpha$ (which characterizes the selectivity of spectral dependence of AOD), and water vapor total content $W$ of the atmo-
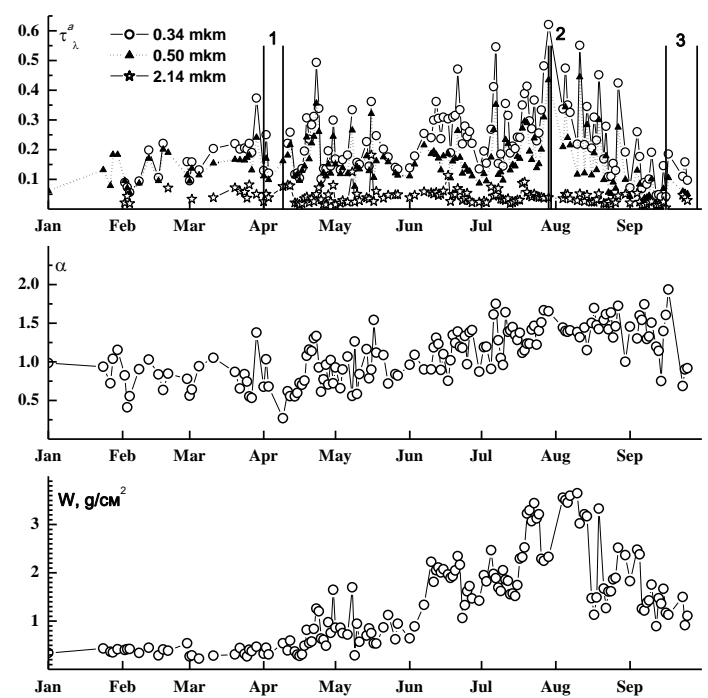

Figure 10. Time variations in the spectral AOD, Ångström exponent $\alpha$, and water vapor total content $W$ in Tomsk during 2013 (lines 1,2 , and 3 show the measurement cycles within the experiment). 

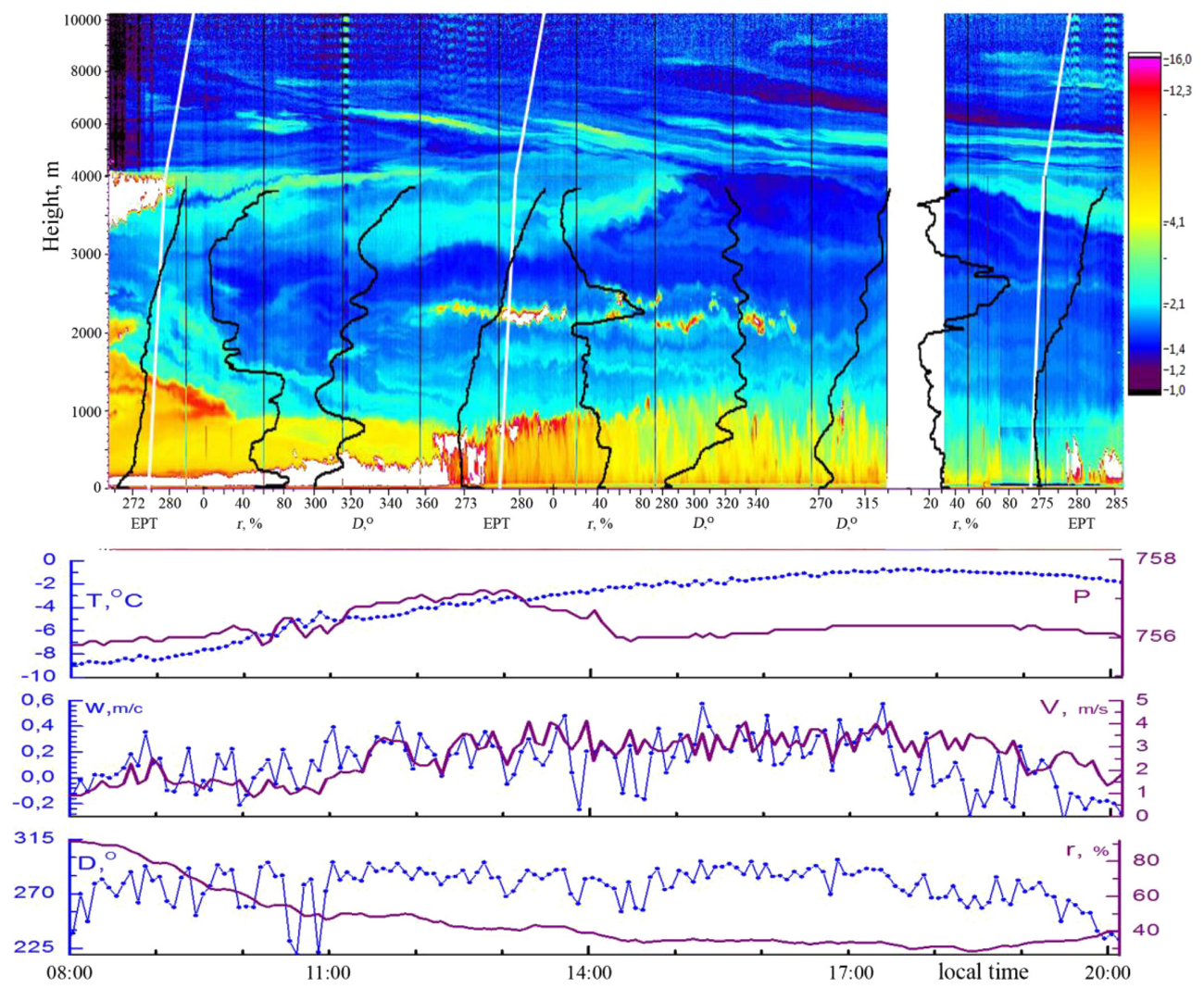

Figure 11. The aerosol structure on 3 April 2013. White lines show the ascent sonde profiles.

sphere at two measuring sites (Tomsk and Fonovaya Observatory) are shown in Fig. 10. Comparison with average annual behavior of AOD, obtained from long-term data, shows that the springtime maximum of atmospheric turbidity did no practically appear in 2013. The main turbidity peak was observed in July-August and was caused by forest fire smokes carried from northern regions (http://fires.kosmosnimki.ru/). The selectivity exponent $\alpha$ ranged from 1 to 1.5 , which is characteristic for a warm period. The character of variations in the water vapor total content corresponds to the average annual behavior, with low values in cold periods and increased values in summer months (with a maximum in August).

A series of experiments on laser sensing of the troposphere was performed from 2 to 11 April 2013; radiosondes were launched in some days. Figure 11 shows two examples of comparison of the aerosol spatial distribution and radiosonde data. Profiles of the backscattering coefficient in units of scattering ratio, defined as the ratio of the total to molecular scattering, are shown on a color scale. The meteorological data (temperature $T,{ }^{\circ} \mathrm{C}$; pressure $P, \mathrm{~mm} \mathrm{Hg}$; vertical $w$ and horizontal $V$ wind velocity, $\mathrm{m} \mathrm{s}^{-1}$; relative humidity $r, \%$; and wind direction $D$, degrees) were measured with the ultrasonic meteorological station, located near the lidar at an altitude of $3 \mathrm{~m}$ above the surface. From the radiosonde data, the relative humidity $r$, the wind direction $D$, and the equivalentpotential temperature in degrees Kelvin are plotted.

As can be seen from Fig. 11, the meteorological situation on 3 April (Tomsk) was characterized by the absence of clouds and considerable surface heating at negative air temperatures. The very dense surface air layer was involved in motion at 12:00 LT, the mixing layer rapidly reached a boundary layer altitude of $1 \mathrm{~km}$, the aerosol density decreases, and wavelike vertical fluxes were observed. The radiosonde profiles for 08:00 LT show a decrease in the relative humidity and a wind shift above the boundary of the boundary layer. In daytime, the relative humidity also decreased above the mixing layer, and the wind shift ceased at this same boundary. In the evening, the mixing layer descended, and its boundary on the humidity profile is indiscernible.

During the project implementation in 2012-2014, we continued the lidar measurements of the optical parameters of stratospheric aerosol layer: the aerosol backscattering coefficient $\beta_{\pi}^{a}$, integral aerosol backscattering coefficient $B_{\pi}^{a}$, and the scattering ratio $R(H)$, defined as the ratio of the sum of aerosol and molecular backscattering coefficients to the latter. Figure 12 shows the integral aerosol backscattering coefficient measured from 1986 to 2014. The arrows show the explosive eruptions of volcanoes, after which increased aerosol content was recorded in the stratosphere over Tomsk. These 


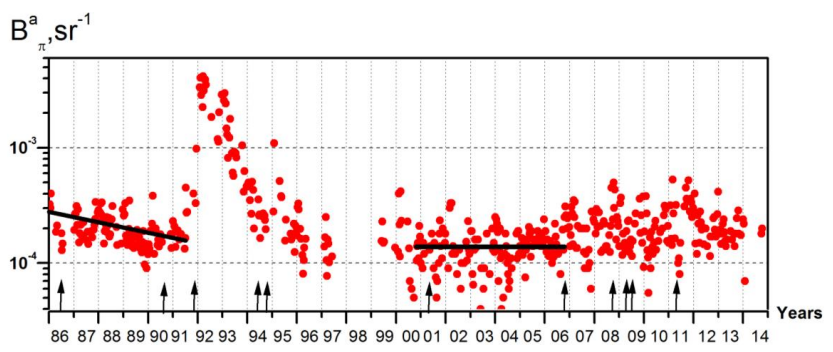

Figure 12. Time variations in the integral aerosol backscattering coefficient at a sensing wavelength of $532 \mathrm{~nm}$ in the altitude range $15-30 \mathrm{~km}$.

data are in good agreement with data from other sites (Ridley et al., 2014).

The comparison of numerical calculation results and values of downward solar radiation fluxes on the Earth's surface measured in the clear-sky atmosphere during summer periods of 2010-2012 in a background region of boreal zone of Siberia shows that relative differences between the model and experimental values of the direct and total radiation, on average, do not exceed 1 and $3 \%$, respectively, when instrumental errors and uncertainties of atmospheric parameters are considered. At the same time, the difference between the model and measurement data only on the direct radiation attains $5 \%$.

The comparison of solar fluxes shows that their differences are mostly smaller or comparable with the uncertainty caused by errors in input parameters and measurements. The analysis also shows that the average differences between empirical data and model calculations are close to results obtained by other authors in other regions (Kato et al., 1997; Henzing et al., 2004; Michalsky et al., 2006; Nowak et al., 2008; Wang et al., 2009; Halthore et al., 1998, 2004; Plakhina et al., 1998; Chubarova et al., 1999). It is important that our results were obtained under the conditions of high and moderate atmospheric transmittance, where the optical depth, scattering phase function, and aerosol single scattering albedo errors increase significantly. This witnesses that models and methods used for retrieve of the optical properties of aerosol provide for generally adequate description of the aerosol radiative effects with accounting for climate conditions of Western Siberia.

\section{Conclusions}

The unique measurement system developed allowed simultaneous measurements of microphysical, chemical, and optical properties of aerosol particles in the surface air layer and free atmosphere with the use of different ground-based, airborne, and spaceborne facilities in order to draw a complete pattern of the composition and state of the atmosphere in the territory of Southwestern Siberia.
The complex aerosol experiment on the measurement of different atmospheric parameters in the Siberian region in 2013 is a first step towards joining the efforts of different research groups aimed at obtaining the as-complete-aspossible information about the state of the atmosphere under conditions of changing climate. Despite the short duration of the experiment, it has shown the potential capabilities of available measuring facilities for longer measurements in the future. In addition, the measurements have revealed some disadvantages. In particular, it was shown that the capabilities of many ground-based and spaceborne instruments for active and passive sensing of the atmosphere are strongly limited by the presence of dense clouds. According to the long-term observations, only 38 cloudless days a year are observed on the average in Tomsk. In this respect, the airborne sensing has an advantage, but the use of the flying laboratory remains limited due to the high cost. Thus, continuous combined observations seem now to be possible only in the atmospheric boundary layer.

Nevertheless, the data obtained during the complex aerosol experiment are of great value both for validation, correction, and calibration of satellite measurements and for validation and improvement of climatic models.

Acknowledgements. This work was supported in part the Russian Science Foundation (agreement no. 14-27-00022 - support for aerosol laser sensing), the Russian Foundation for Basic Research (grants 13-05-98074, 13-05-00096, 14-05-00526, 14-05-00590), and the President of the Russian Federation (grant NS-4714.2014.5 in support of leading scientific schools).

Edited by: A. Kokhanovsky

\section{References}

Anokhin, G. G., Antokhin, P. N., Arshinov, M.Yu., Barsuk, V. E., Belan, B. D., Belan, S. B., Davydov, D. K., Ivlev, G. A., Kozlov, A. V., Kozlov, V. S., Morozov, M. V., Panchenko, M. V., Penner, I. E., Pestunov, D. A., Sikov, G. P., Simonenkov, D. V., Sinitsyn, D. S., Tolmachev, G. N., Filipov, D. V., Fofonov, A. V., Chernov, D. G., Shamanaev, V. S., and Shmargunov, V. P.: OPTIK Tu-134 aircraft laboratory, Atmos. Ocean. Opt., 24, 805-816, 2011.

Arshinov, M. Yu., Belan, B. D., Davydov, D. K., Ivlev, G. A., Kozlov, A. V., Pestunov, D. A., Pokrovskii, E. V., Tolmachev, G. N., and Fofonov, A. V.: Sites for monitoring of greenhouse gases and gases oxidizing the atmosphere, Atmos. Ocean. Opt., 20, 45-53, 2007.

Chubarova, N. E., Rublev, A. N., Trotsenko, A. N., and Trembach, V. V.: Comparisons between modeled and measured surface shortwave irradiances under clear sky conditions, Izv. Atmos. Ocean. Phys., 35, 201-216, 1999.

Dubovik, O. and King, M.: A flexible inversion algorithm for retrieval aerosol optical properties from Sun and sky radiance measurements, J. Geophys. Res., 105, 20673-20696, 2000. 
Dubovik, O., Holben, B., Kaufman, Y., Yamasoe, M., Smirnov, A., Tanre, D., and Slutsker, I.: Single-scattering albedo of smoke retrieved from the sky radiance and solar transmittance measured from ground, J. Geophys. Res., 103, 31903-31923, 1998.

Dubovik, O., Smirnov, A., Holben, B., King, M., Kaufman, Y., Eck, T., and Slutsker, I.: Accuracy assessments of aerosol optical properties retrieved from Aerosol Robostic Network (AERONET) Sun and sky radiance measurements, J. Geophys. Res., 105, 9791-9806, 2000.

Eremenko, S. and Ankilov, A.: Conversion of the diffusion battery data to particle size distribution: multiple Solutions Averaging algorithm (MSA), J. Aerosol Sci., 26, 749-750, 1995.

Gladkikh, V. A. and Makienko, A. E.: Digital ultrasonic meteostation, Pribory, 109, 21-25, 2009.

Gladkikh, V. A., Makienko, A. E., and Fedorov, V. A.: Volna-3 Doppler sodar, Atmos. Ocean. Opt., 12, 422-429, 1999.

Gladkikh, V. A., Kamardin, A. P., and Nevzorova, I. V.: Determination of internal mixing layer height from "Volna" sodar measurements, Atmos. Ocean. Opt., 22, 1154-1159, 2009.

Halthore, R. N., Nemesure, S., Schwartz, S. E., Emre, D. G., Berk, A., Dutton, E. G., and Bergin, M. H.: Models overestimate diffuse clear-sky irradiance: a case for excess atmospheric absorption, Geophys. Res. Lett., 25, 3591-3594, 1998.

Halthore, R. N., Miller, M. A., Ogren, J. A., Sheridan, P. J., Slater, D. W., and Stoffel, T.: Further developments in closure experiments for diffuse irradiance under cloud-free skies at a continental site, Geophys. Res. Lett., 31, L07111, doi:10.1029/2003GL019102, 2004.

Henzing, J. S., Knap, W. H., Stammes, P., Apituley, A., Bergwerff, J. B., Swart, D. P. J., Kos, G. P. A., and ten Brink, H. M.: Effect of aerosols on the downward shortwave irradiances at the surface: measurements vs. calculations with MODTRAN4.1, J. Geophys. Res., 109, D14204, doi:10.1029/2003JD004142, 2004.

Holben, B. N., Eck, T. F., Slutsker, I., Tanre, D., Buis, J. P., Setzer, A., Vermote, E., Reagan, J. A., Kaufman, Y. J., Nakadjima, T., Lavenu, F., Jankowiak, I., and Smirnov, A.: AERONET - a federated instrument network and data archive for aerosol characterization, Remote Sens. Environ., 66, 1-16, 1998.

Kato, S., Ackerman, T. P., Clothiaux, E. E., Mather, J. H., Mace, G. G., Wesely, M. L., Murcray, F., and Michalsky, J.: Uncertainties in modeled and measured clear-sky surface shortwave irradiances, J. Geophys. Res., 102, 25881-25898, 1997.

Kozlov, V. S., Panchenko, M. V., Tumakov, A. G., Shmargunov, V. P., and Yausheva, E. P.: Some peculiarities of the mutual variability of the content of soot and submicron aerosol in the nearground air layer, J. Aerosol Sci., 28, S231-S232, 1997.

Kozlov, V. S., Panchenko, M. V., and Yausheva, E. P.: Mass fraction of Black Carbon in submicron aerosol as an indicator of influence of smokes from remote forest fires in Siberia, Atmos. Environ., 42, 2611-2620, doi:10.1016/j.atmosenv.2007.07.036, 2008a.

Kozlov, V. S., Shmargunov, V. P., and Pol'kin, V. V.: Spectrophotometers for investigation of characteristics of radiation absorption by aerosol particles, Prib. Tekh. Eksp., 5, 155-157, 2008b.

Marenco, A., Thouret, V., Nedelec, P., Smit, H., Helten, M., Kley, D., Karcher, F., Simon, P., Law, K., Pyle, J., Poschmann, G., Von Wrede, R., Hume, C., and Cook, T.: Measurement of ozone and water vapor by Airbus in-service aircraft: the MOZAIC airborne program, an overview, J. Geophys. Res.-Atmos., 103, 2563125642, 1998.
Michalsky, J. J., Anderson, G. P., Barnard, J., Delamere, J., Gueymard, C., Kato, S., Kiedron, P., McComiskey, A., and Ricchiazzi, P.: Shortwave radiative closure studies for clear skies during the Atmospheric Radiation Measurement 2003 Aerosol Intensive Observation Period, J. Geophys. Res., 111, D14S90, doi:10.1029/2005JD006341, 2006.

Monnin, E., Indermuhle, A., Dallenbach, A., Fluckinger, J., Stauffer, B., Stocker, T. F., Raynaud, D., and Barnola, J.-M.: Atmospheric $\mathrm{CO}_{2}$ concentrations over the last glacial termination, Science, 291, 112-114, 2001.

Nowak, D., Vuilleumier, L., Long, C. N., and Ohmura, A.: Solar irradiance computations compared with observations at the Baseline Surface Radiation Network Payerne site, J. Geophys. Res., 113, D14206, doi:10.1029/2007JD009441, 2008.

Odintsov, S. L. and Fedorov, V. A.: Investigation of wind velocity variations on mesometeorological scale from sodar observations, Atmos. Ocean. Opt., 20, 900-906, 2007.

Plakhina, I. N., Repina, I. A., and Gorchakova, I. A.: Comparison between measured and calculated radiation fluxes reaching the Earth's surface, Izv. Atmos. Ocean. Phys., 34, 112-119, 1998.

Ridley, D. A., Solomon, S., Barnes, J. E., Burlakov, V. D., Deshler, T., Dolgii, S. I., Herber, A. B., Nagai, T., Neely III, R. R., Nevzorov, A. V., Ritter, C., Sakai, T., Santer, B. D., Sato, M., Schmidt, A., Uchino, O., and Vernier, J. P.: Total volcanic stratospheric aerosol optical depths and implications for global climate change, Geophys. Res. Lett., 41, 7763-7769, doi:10.1002/2014GL061541, 2014.

Sakerin, S. M., Kabanov, D. M., Rostov, A. P., Turchinovich, S. A., Turchinovich, and Yu, S.: System for the network monitoring of the atmospheric constituents active in radiative processes, Part 1. Sun photometers, Atmos. Ocean. Opt., 17, 314-320, 2004.

Sakerin, S. M., Kabanov, D. M., Rostov, A. P., Turchinovich, S. A., and Knyazev, V. V.: Sun photometers for measuring the spectral atmospheric transparency under stationary and mobile conditions, Atmos. Ocean. Opt., 25, 1112-1117, 2012.

Samoilova, S. V., Balin, Yu. S., Kokhanenko, G. P., and Penner, I. E.: Investigation of the tropospheric aerosol layer vertical distribution from the data of sensing with a multifrequency Raman lidar, Part 1. Methods for the reconstruction of optical parameters, Atmos. Ocean. Opt., 22, 344-357, 2009.

Shmargunov, V. P. and Pol'kin, V. V.: AZ-5 based aerosol counter, Prib. Tekh. Eksp., 2, 165-166, 2007.

Shmargunov, V. P., Kozlov, V. S., Tumakov, A. G., Pol'kin, V. V., and Panchenko, M. V.: FANbased automated aerosol nephelometer, Prib. Tekh. Eksp., 5, 165-167, 2008.

Shmargunov, V. P., Pol'kin, V. V., Tumakov, A. G., Panchenko, M. V., and Pol'kin, V. V.: Closed volume aureole photometer, Prib. Tekh. Eksp., 6, 155-157, 2010.

Solomon, S., Qin, D., Manning, M., Chen, Z., Marquis, M., Averyt, K. B., Tignor, M., and Miller, H. L.: Climate Change 2007: The Physical Science Basis, Contribution of Working Group I to the Fourth Assessment Report of the Intergovernmental Panel on Climate Change, IPCC AR4 WG1, Cambridge University Press, Cambridge, UK, New York, NY, USA, 996 pp. 2007.

Wang, P., Knap, W. H., Munneke, P. K., and Stammes, P.: Clear-sky shortwave radiative closure for the Cabauw baseline surface radiation network site, Netherlands, J. Geophys. Res., 114, D14206, doi:10.1029/2009JD011978, 2009. 